\title{
Historical Archaeo-Geographies of Scaled Statehood: American Federalism and Material Practices of National Prohibition in California, 1917-1933
}

\author{
Anne E. Mosher, Department of Geography, The Maxwell School \\ of Citizenship and Public Affairs, Syracuse University, 144 Eggers Hall, \\ Syracuse, NY 13244, USA \\ E-mail: amosher@maxwell.syr.edu
}

Laurie A. Wilkie, Department of Anthropology, University of California, 232 Kroeber Hall, Berkeley, CA 94720, USA

E-mail: lawilkie@berkeley.edu

\begin{abstract}
This paper discusses the ways that a more explicit engagement with the discipline of historical geography could contribute to archaeologies of the recent and contemporary past. Scholars working in this time period must consider multiple scales of connectivity between people and places through time and would benefit from political geography's recent theorizing on scale and the state. We present a preliminary case study of what we term a historical archeo-geography drawing upon archaeological materials from late nineteenth to mid-twentieth century sites to demonstrate how state and federal legislation is enacted at the household level.
\end{abstract}

Résumé: Cette étude aborde de quelles façons une participation plus affirmée pour la discipline de la géographie humaine pourrait favoriser les archéologies du passé récent et du passé contemporain. Les universitaires qui travaillent sur cette période doivent prendre en compte les niveaux multiples de relation qui existent entre les individus et les lieux à travers le temps; ils bénéficieraient de la théorisation récente sur l'échelle en matière de géographie humaine et de l'État. Nous présentons une étude de cas préliminaire de ce que nous appelons l'archéogéographie historique, en nous appuyant sur les objets archéologiques provenant de sites de la fin du XIXe siècle jusqu'au milieu du XXe siècle pour montrer comment la législation des États et de la fédération se traduisait en pratique dans les foyers. 
Resumen: El presente trabajo plantea la cuestión de si un compromiso más explícito con la disciplina de la geografía humana podría ayudar en los trabajos arqueológicos del pasado reciente y contemporáneo. Los académicos que trabajan en este periodo de tiempo deben tener en cuenta varias escalas de conectividad entre las personas y los lugares a través del tiempo, con lo que se beneficiarían de la reciente teoría sobre geografía humana centrada en la escala y el estado. Presentamos un estudio de caso previo de lo que hemos denominado «arqueogeografía histórica», basándonos en materiales arqueológicos procedentes de yacimientos de finales el siglo XIX y xx, para demostrar cómo se aprueba la legislación estatal y federal a escala interna.

\section{KEYWORDS}

Spatiality, Historical archaeology, Historical geography, Political geography, California, Eighteenth Amendment

\section{Introduction}

Archaeologies of the recent and contemporary past have become more prominent in the last 10 years, with projects developing throughout Europe, the Caribbean, North and South America, Australia and Africa (e.g. Buchli and Lucas 2001a; Hicks and Beaudry 2006; Johnson 2007; Majewski and Gaimster 2009). There are increasingly two genres found within these archaeologies: first, a more empirical, excavation-based approach, which is most commonly found in the United States tradition, but elsewhere as well (e.g. Beaudry 2006; Hicks 2007; Voss 2008; Wilkie 2010); and, second, a more aesthetically rooted approach that seeks to document and describe archaeological traces of the modern (e.g. Buchli and Lucas 2001b; GonzalezRuibal 2006; Holtorf 2004) Both genres produce important work, bringing an archaeological gaze to questions of colonialism, post-colonialism, racism, sexism and alienation in the modern world. What has been an enduring and ongoing problem for these projects has been the question of spatial scale-how to integrate microscalar site-oriented archaeological analyses meaningfully into macroscalar synoptic understandings of political, social and economic contexts. This has been particularly true for American historical archaeology. While it has become quite adept at creating intimate portraits of isolated archaeological assemblages from households or small communities, it is less successful at integrating materials across space and time in 
sophisticated ways. Some of the more convincing studies have drawn explicitly upon understandings of landscape and the notion of 'spatiality' as developed within the academic field of human geography.

We suggest that archaeologists would benefit by drawing more explicitly upon further engagement with the intellectual and analytical tools of human geography (specifically, from the human geography subfields known as historical geography and political geography). While this paper will focus in most detail upon our first efforts to integrate archaeological and geographical scales of knowledge as a means to understand the effects of the political system of federalism on individual and community lives, the issues that we are struggling with are relevant to anyone studying sites of the recent and contemporary past-sites that were enmeshed in social and political relations that connected them simultaneously to people across the street, across the globe as well as to the state apparatus.

A call for more human geography-archaeology interaction is somewhat radical in the United States, where the disciplines of anthropology and geography have not shared the same kind of cross-pollination sometimes seen in the U.K. The relationship between the disciplines has fostered a divide between anthropology's subdiscipline of historical archaeology and human geography's subdiscipline, historical geography. This divide, although explainable, seems strange to us given the practices and goals we share in common (but have developed independently). We offer some possible explanations for the American divide, but our primary goal is to build a bridge across the divide through the development of the transdisciplinary practice of historical archaeo-geography. We offer a demonstration of this practice through a study that weds: (1) existing social science theory regarding the spatiality of political statehood with (2) long-standing historiographic debates from academic history regarding the nature of American federalism and use them to interpret (3) material practices at home, in private clubs, and in the commercial built environment of California during the era of National Prohibition (1920-1933). Underpinning this historical archaeo-geographic approach, we argue, are concerns for understanding spatiality and the multi-scalar nature of human existence. The approach's engagement with 'state spatial theory' highlights how strong, universal attempts at state hegemony can generate spatially differentiated material practices of compliance and non-compliance by the human subject under American federalism. We recognize that this study is still quite preliminary, but feel that at a time when historical sites are being excavated at an increasing rate, the question of how to meaningfully interpret, synthesize and contextualize this vast amount of data cannot wait. 


\section{Mind the Gap: The Separation of Historical Geography and Historical Archaeology in the United States}

Historical geographers and historical archaeologists view and think about the world in similar ways. We recognize that there is a materiality and spatiality to the lived world (Mitchell 2000). We share concern for space and place in time (synchronicity) and over time (diachronicity) (Mitchell 1987). We have an intense commitment to the archives and to the triangulation of primary documentary evidence (Conzen 1993). Given our objective focus on things in the landscape, however, we are necessarily drawn away from the archives, the Ivory Tower and into the field to observe, count, and map (Earle et al. 1989). And yet with few exceptions (see Butzer 1964, 1976, 1982; Butzer et al., 1974; Butzer and Omo Research Expedition 1971; Denevan et al. 1986), historical geographers and historical archaeologists of the recent past who reside in the U.S. academy have not actively collaborated outside the realm of contract archaeology or staterequired impact statement preparation. Why?

Institutional mismatches that exist within American "Research-1" universities may be part of the explanation. Few anthropology departments with specializations in historical archaeology are located at institutions with geography departments that specialize in historical geography. Furthermore, from the 1930s until the late 1970s, academic geography in the U.S. developed in relative isolation given the pressure it was under to prove continually its relevance as a stand-alone discipline within the American university (Hartshorne 1939; Smith 1987). Although the field embraced and built upon the work of other disciplines during that period, active collaborative partnership with those outside of academic geography happened sporadically, in isolated cases, under quite institutionally idiosyncratic conditions, and mainly within the realm of 'regional science' (the academic cross-pollination of urban economic geography and urban and regional economics). Institutional pressures have started to ease over the past 30 years, however. The 'spatial turn' in the social sciences and humanities in the 1970s made the work of geographers more relevant to those outside the field (Warf and Arias 2009) while the 'cultural turn' in geography during the 1980s encouraged humanistic and cultural geographers to engage contemporary social theory as espoused in critical textual studies (Jameson 1998) and anthropology. Additionally, the general public's recognition of the globalization factor in the 1990s convinced educators and public policy makers that geography education matters at the primary and secondary-school levels and, in turn, that geography is an important part of American higher education (Geography Education Standards Project (U.S.) et al. 1994; Herod 2009; Murray 2006). Finally, in the 2000s, physical geographers were accepted within the 
American academy as bona fide earth scientists and their participation is routinely solicited in large, trans-disciplinary research projects that address important societal (if not global) issues (De Blij 2005).

Despite American geography's relative isolationism through much of the twentieth century, the field did have a relationship with anthropology that went beyond geographers simply reading the work of anthropologists or anthropologists relying on the published work of geographers to "set the environmental stage" for the action reported in traditional ethnography. Two places figured importantly in that relationship as it was forged and maintained between the 1920s and 1970s: the University of California at Berkeley and Louisiana State University. Together, anthropologists and geographers in these places defined a "school" of cultural geography/ anthropogeography that had huge impacts on the development of human geography in the United States, causing it to diverge from human geography as practiced elsewhere in the Anglophone world.

Key figures in this American school were Carl O. Sauer (a professor of geography at Berkeley between the 1920s and 1960s) and Sauer's third student, Fred B. Kniffen (who became a professor of geography at LSU in the 1930s and trained students well into the 1970s) (Conzen 1993). Both were cultural diffusionists and disciples of the culture region concept, heavily influenced not only by German geographers such as Carl Ritter and Friedrich Ratzel, but also through their personal interactions with anthropologists at Berkeley, especially Alfred Kroeber. Together, Sauer and Kniffen attracted and trained more than 50 Ph.D. students in their hybrid anthropo-geographical approach that privileged a 'superorganic' notion of culture, who then moved on to academic appointments at several dozen American universities. Ultimately, these scholars became the core practitioners to one of two major subdisciplines that dominated human geography in the United States (idiographic regional economic geography being the other) until the 1960s when the British 'brain drain' accentuated quantitative, nomothetic, logical positivism within the American academic mix (Johnston 2004).

Despite substantive interactions with anthropologists-particularly at LSU where geography has actually shared a department with anthropology since 1941, members of the Berkeley/LSU School of Cultural/Anthropogeography seldom maintained active collaborative research alliances with anthropologists once they left their alma maters. Most of the cultural geographers and anthropogeographers working between 1930 and 1980 in the United States could trace their intellectual genealogies directly back to Sauer (largely through Kniffen), but they had become diluted in geography department faculties that consisted of many other disciplinal sub-specialties (like urban and economic geography, cartography and climatology) that in the 1960s and 1970s were increasingly regarded as more important than cultural and anthropogeography to geography's search for academic relevance 
(Staeheli and Mitchell 2005). By the early 1980s, the Berkeley/LSU School was regarded by many within academic geography as an anachronism.

A broader, reinvigorated, rapprochement between American anthropology and geography did not really begin until-first-the emergence of urban anthropology and it's discovery of space and place via urban sociology and then via urban geography during the 1970s and 1980s, and second, American cultural geography's reorientation in the 1980s away from Kroeber, Sauer and Kniffen's objectivist, superorganic notions of culture, toward British constructivism and French social theory (Duncan 1980; Low and LawrenceZúñiga 2003; Price and Lewis 1993). The move toward social theory within cultural geography is particularly important for it represented a critique not only of Sauer and Kroeber but also an interrogation of trends that had emerged elsewhere in human geography-namely, economic and behavioral geographies' positivist reduction of the human subject into homo economicus.

Since then, both historical archaeology and historical geography have responded to these shifts within their sibling subfields cultural anthropology and cultural geography. They have started struggling (separately) over theoretical and methodological issues regarding human subjects, most notably those revolving around structure-agency relationships as played out in families, communities, states and nations, and as manifested through everyday lived experience (Pile 1993). Both have grappled with what it is to study capitalist societies and the constraints, opportunities, hegemonies, freedoms, impositions, and abuses that come with living in that economic system (e.g. Harvey 1973, 1989a, b; Leone 2006; Ludlow Collective 2001; Mitchell 1996; Mosher 2004; Mullins 1998; Wilkie and Bartoy 2001). And yet, there still has not been much active transdisciplinary collaboration between historical archaeologists and historical geographers in the United States on issues of shared theoretical concern.

\section{Historical Archaeo-Geography: “Ground Up” Meets "Top Down"}

Despite the re-emergence of inductive "grounded theory"-building as an acceptable form of practice in the social sciences during the 1990s, both academic historical geography and academic (but not contract or applied) historical archaeology have tended since at least the 1970s to initiate their work from abstract positions-drawing upon social/literary theory or historiography-for justification, inspiration and motivation (Creswell 2003; Earle 1992). From theory/historiography, they move into the empirical realm to: (1) construct an interpretation of what is encountered in the empirical realm in light of theory and historiography; and (2) use the empirical realm as a way to critique, improve upon, and reformulate 
the initiating theory and historiography. Where the fields vary, however, is the resolution at which they start to do this. Traditionally, archaeologists work on and under the ground and extrapolate 'upwards and out'; the object(s) of study is (are) the artifact, the unit, the assemblage, the site. The geographer's tradition, however, is to start more often from a detached 'god position' that uses the map or landscape as the initial object of study; interpolation occurs 'down and between' (Rose 1997). Drawing upon the work of Michel de Certeau, one could go as far as to say that archaeologists tend to create spatial stories of the "tour" (local everyday life as experienced in situ) while geographers create spatial stories of the "map" (broad complex systems as viewed cartographically or obliquely from a distance) (Certeau 1984). The challenge for historical archaeo-geography is to meld these two approaches.

Indeed, archaeologists like Charles Orser (1996) have called for historical archaeology to work at a global scale, and scholars within the field have begun to construct multi-sited projects to look more explicitly at colonial systems and diasporic movements (e.g. Beaudry 2006; Hall 2000; Lightfoot 2006; Ogundiran and Falola 2007; Orser 2007), but these kinds of broad syntheses - the very work that geographers have long been doing-remain underdeveloped within archaeology. The world is not simply the site or a sample of sites set within the global-other scales matter, such as the locality, the regional, the national, and the supranational alliance. The site is nested within them all, a point that human geographers have been working hard to theorize since the late 1970s through their study of the neoliberal restructuring of statehood and the globalization of capitalism (Brenner 2001; Dear 1988; Marston 2000).

With some human geographers sliding away from nomothetic logical positivism as well as superorganicism since the 1970s and 1980s, there has been a move within the field to understand the spatiality of life as performed and experienced by the human subject. And, although historical geographers (as subdisciplinary members of human geography) were actually part of the vanguard within this movement through their interests in locality studies and the urban experience, they still tended to aggregate the primary evidence and use the experience of the individual human subject only for anecdotal flavor (Earle et al. 1989; Harvey 1985), simply because there was not enough material available to say something systematic and scientifically grounded. Until the rise of feminist theory within historical geography, historical geographers tended only to use the official and masculinist-oriented archival record as the main means to understand experience-and that record has been fragmented at best (Domosh and Morin 2003; Kay 1991; Morin and Berg 1999; Rose and Ogborn 1988). Now, engagement with feminist theory, in particular, and postmodernism, in general, has raised questions about positionality and provenance and 
subjectivities of various sorts, and has transformed oral history and folklore into acceptable ways to engage the human subject in the past (Earle 1995). Archaeology also has established itself as another means of approaching past lives (e.g. Beaudry 2006; Brooks et al. 2008; Voss 2008; Wilkie 2003, 2010).

\section{Three Pillars of Historical Archaeo-Geography and Their Relationship to Spatiality and Scale}

As we explore the possibilities for historical archaeo-geography, we believe it would be helpful to erect this practice on three epistemological pillars that already motivate knowledge production within both contemporary historical archaeology and historical geography: (1) the engagement with theory from the social sciences and humanities, (2) the framing of research questions within broader historiographic debates from academic history, and (3) the concern for the empirical realm as it is encountered through artifacts, assemblages, sites, landscapes, places, archival sources, and human subjects. Although historical geographers and historical archaeologists move between these pillars in slightly different ways methodologically, what links their methods is concern for spatiality. That is, historical archaeologists and historical geographers are always looking for and thinking about the meaning of simultaneously occurring sets of relationships that exist between empirical objects (or subjects) encountered in three or more locations. Because of their concern for these spatial relationships, concepts like near/far (distance), wide/narrow (area), clustered/dispersed (density), connected/isolated (accessibility), enclosed/open (topology), shallow/deep (volume), and found/lost (presence), become critical adjectives within their attendant languages of practice. Furthermore, to their fields, cartographic representations of these concepts fulfill an analytic (as opposed to idiographic) function. In fact, primary analytic engagement with spatiality via the map distinguishes archaeology and geography from other social sciences and the humanities.

Important to our current collaboration, should be a new notion, however-one that has been pioneered largely by political, economic and urban geographers who study the contemporary (post-1980) empirical realm. This is the idea that spatiality is not only embedded within, but also has the capacity to create, 'scale.' By scale, these geographers are not referring to conventional, popular definitions of the concept (e.g. the mathematical and proportional relationship that exists between a 'real life' object or distance and its representation in a photograph or on a map, or even "resolution.") Instead, their view of scale argues two basic points: first, that material objects (and corporeal subjects) occupy physical space and have mass, the extent and shape of which constitutes 'the scale of the thing' (or body). Second, the co-existence of, and the interaction that occurs 
between, things and bodies in space create 'relational scales.' In this sense, scale is the spatial extent-the far horizons-as well as the internal configuration of the field in which objective things and subjective bodies co-exist, operate and have meaning.

For human-made objects and human subjects, both 'the scale of the thing' and 'relational scale' are socially produced. Human geographers who employ a political economy approach, for example, argue that within capitalist society, scale is created through: (1) the appropriation and transformation of nature into manufactured objects through human labor power; (2) the development of the wage relationship between capital and labor as it extends through labor markets, and (3) by the invention, adoption and adaptation of manufacturing, transportation and communication technologies that diffuse throughout entire industries and economies. Natural resources, factories, residential neighborhoods, warehouse districts, rail lines, telephone cables-and the functional relationships that are made by human subjects to exist between them-create a variety of scales, e.g. the local mining or industrial district, the regional corporate system, the national marketing and distribution system, the global network of financial capital, etc.

Scale, however, is a dynamic and, at times, ephemeral abstraction. It can expand, contract, 'nest' like Russian dolls inside of other scales, and even disappear altogether if the object or subject ceases to exist or if economic, caloric, and psychological costs of overcoming distance become too great. Moreover, objects can be moved and subjects can move between scales-sometimes operating in a geographically limited realm (the local scale) while at other times 'scaling up' or 'jumping scale' to become a part of longer distance trade or strategic relationships (e.g. the European Union).

In this paper, this understanding of scale forms the theoretical pillar to our historical archaeo-geographic interpretation of National Prohibition (1920-1933). It illuminates the critical role that multi-scaled 'statehood' plays in shaping material culture within the overlapping spheres of productive capital and reproductive labor. By using the term statehood, we are referring to the structure and performance of the political state. We must acknowledge, however, that statehood is not completely new terrain to either historical archaeologists or historical geographers. They have previously grappled with it in their study of colonialism, post-colonialism, slavery, the planning of urban infrastructure, and the construction of national identity. As historical archaeology and historical geography shift more attention toward the period that historian Konvitz (1985) refers to as the regulatory era of western civilization (the century after 1880) during which governments legislated social relations and environmental conditions at the local level to a greater degree than ever before, statehood is going to become an even more essential category to the analysis. Artifacts, assemblages, sites, landscapes, places, archival records, and human subjects 
produced in the late nineteenth and twentieth century all make more sense when statehood is taken into consideration. We can think of no better example of how to illustrate this argument than to show the tangible manifestations of statehood in place and assemblage as they occurred during National Prohibition. In the United States, these manifestations are to this very day all around us.

\section{State Theory, Statehood and Federalism}

Within geography, much of the recent theorizing about scale and statehood has engaged two things: (1) the differential ability that subjects have to construct the local worlds they inhabit while living within larger hegemonic structures of capitalism and state power (Mosher and Holdsworth 1992); and (2) the alleged decline since 1980 in the importance of the nation-state as the governmental level that calls the political shots and the scale that contains the bulk of economic interactions (such as those performed by the corporation and the NGO) (Brenner 2004; Marston 2000; Marston et al. 2005). In both cases, changes in statehood generate ripple effects of varying consequence to the materiality, spatiality and experience of everyday, local, life that occurs within a state's territory.

For the study of the United States, the study of statehood requires theoretical and empirical engagement with the structure and performance of the political system of federalism. As a structural form, federalism is based on the idea that legislative, administrative, and judicial responsibilities for governance are to be shared between different levels of the state in the form of subnational (local and regional) and national (central) governments (Dikshit 1971, 1976; Elazar 1981). Further, each level exists at the pleasure of the others: thus as relational scales these levels are mutually constituted. The central/national level (called the federal government in the United States) exists due to the assent of the sub-national levels in its exercising of the ability to act on behalf of sub-national levels on matters as enabled by the U.S. Constitution. As for the sub-national levels (the 50 states, and the thousands of counties, cities, towns and other minor civil divisions that exist below), they are at once granted and retain the right to govern themselves and to enact legislation that is appropriate to local conditions. Through their initial ratification of the U.S. Constitution the 50 (or 'several') states (and the jurisdictions beneath them) have also pledged (in theory if not always in practice) to honor the powers of the federal government. Thus federalism as a form of statehood attempts to foster unity at the national level while preserving some degree of regional diversity and local opinion at the subnational levels: e pluribus unum. 
In terms of performance, federalism under the U.S. Constitution also amounts to the designation and apportionment of responsibility for different kinds of activities between all levels/scales, with the federal government being most concerned with issues that will preserve republican unity (e.g. internal commerce, sovereign identity, international relations and military protection that construct the national scale), and with sub-national governments being most concerned with issues that allow for democratic engagement on the part of the citizenry (e.g. public health, education, welfare, and protection of private property that construct the local scale) (Mettler 1998; Skocpol 1992). What is notable about the history of statehood within the U.S. is that this designation and apportionment has been in constant flux in response to changes in capitalism and periodic dialectical swings in political attitudes between protectionist elitism and free-trade egalitarianism (Earle 2003). At times during this historical progression, the federal level has taken on more responsibility for activities traditionally performed by local levels of government (or the private sector) in an attempt to ensure consistent availability to all citizens. This amassing of new tasks is referred to as 'state formation.' At other times, the federal level has delegated some of its responsibilities down to the sub-national levels in the belief that local governments have a better sense of what citizens really need (or that the private sector can do a better job at providing the service). This offloading of existing tasks is referred to as 'state devolution.'

So what can we learn about these processes of state formation and state devolution through the archaeological record, from the local built environment, and via the map? How did they operate during the era of National Prohibition? What light do they shed on the assemblage, the landscape, and the primary documentary evidence?

\section{National Prohibition Legal Geographies and Historiographies}

When the U.S. Congress passed the Eighteenth Amendment to the Constitution in December 1917, it banned the manufacture, transportation, sale and importation of intoxicating alcoholic beverages (ratification by twothirds of the U.S. States came in 1919 and enforcement began in 1920). This congressional act served as an exclamation point to a nearly century-long reform movement intended not only to eradicate the moral and social evils of alcohol but also to curb the growing influence of 'saloon politics' in American society (Blocker 1976). Machine politicians (such as those associated with New York's Tammany Hall Democrats) as well as socialist and free-thinking organizations in many places had come to rely on the urban bar room as a locus for support (Powers 1998). The story of national state 
intervention regarding alcohol and the saloon was far from settled by the Amendment, however, having really been complicated by the prior actions of many of the (then) 48 U.S. States as well as by hundreds of counties and minor civil divisions that had already exercised 'local option' by enacting their own legislation. The pattern of laws they had created could be described almost as a patchwork quilt-with some localities enacting total (and probably unconstitutional) bans on alcohol sales, purchase and possession; others adopting partial bans (the model ultimately exercised with the Eighteenth Amendment); and others doing absolutely nothing (Spaeth 1991).

The geographical problem that the sub-national governments had created prior to the Eighteenth Amendment was thus one of official 'extramurality' - similar to the sort of pattern that Vance (1990) identified in the medieval relationship between guild-controlled walled European bourgs and the seigniorial faubourgs that had grown up on the other side of their gates. The 'intramural' bourg side of the wall had its own legal codes while the 'extramural' faubourg had another. What this meant was that many activities that truly were necessary for the continued productive and reproductive existence of the bourg (but that the bourgeoisie thought to be too dangerous or disruptive if located in the bourg itself) ended up being effectively 'zoned out' of the bourg and into the faubourg. These activities often included livestock slaughtering, rendering, and tanning, as well as burial of the dead and care of the acutely sick.

In the jurisdictional geography of the late-nineteenth and early twentieth-century United States, places that legalized alcohol consumption and gambling (and that often turned a blind eye to prostitution), became the equivalent of faubourgs. And because the U.S. Constitution protected the freedom of Americans to travel and to conduct business across jurisdictional boundaries, citizens living in bourg-like jurisdictions that possessed strict alcohol laws simply went to the faubourg-like jurisdictions with lax rules and enforcement that would allow them to drink or to buy booze. Some localities even took advantage of their extramural status to stimulate the local economy, becoming in the process magnets and havens for vice. Thus to deal effectively with the alcohol issue, restrictions had to be "scaled up" to the national level of the federal state so that regulation would cover more territory (Uvin 1995). That was the only way in which the officially mandated pattern of extramurality could be evened out. Besides, Prohibition seemed to be emerging as a global trend, with other countries passing their own bans on alcoholic substances. Thus the push for National Prohibition was really an argument in favor of national state formation and its ability to even out inter-jurisdictional differences.

The real problem with Prohibition came, however, not so much with the constitutional amendment itself, but rather with the subsequent 
congressional legislation that enabled the amendment's enforcement. Called the Volstead Act of 1919 (after its sponsor in the House of Representatives), the bill had been primarily written by the head of one of the most organized and vocal pro-Prohibition groups, the Anti-Saloon League (Kyvig 2000). It defined any substance that possessed an alcohol content of greater than $0.5 \%$ as intoxicating, and-hence-illegal. Most Americans, as well as their Congressional representatives at the national level (who had already passed the Eighteenth Amendment) and state legislators who worked at the sub-national level (who then ratified the amendment) believed that the enforcing legislation (that had not yet been written at the time of the amendment's passage and ratification) would simply adopt the $2.5 \%$ alcohol content definition that had been used during World War I when curbs had been placed on alcohol manufacture due to grain shortages. As always, the devil was in the details; the Anti-Saloon League wrote a much more stringent law. Nevertheless, the bill sailed through a Congress that was filled with legislators who believed that this is what their constituents wanted, a correct assumption in theory but an errant one in practice.

Historian Kyvig (2000) estimates that after 1920 alcohol consumption dropped in the United States over 60\%. Certainly, part of the reason for the drop had to do with a reformation of American social behavior in light of commonly cultural held ideals. A more structural economic reason, however, resided in the laws of supply and demand: the diminished supply caused by distillery, brewery and winery closures had caused alcohol prices to skyrocket, and made spirits, beer, and wine unaffordable to many Americans. Alcohol was nevertheless legally available if one wanted to acquire it due to a legal loophole in which physicians could write medical prescriptions for alcohol and pharmacists could dispense it. Once the loophole was closed through further legislation, home brewing, clandestine homemade stills that produced small batches of spirits, and bootleg smuggling each became major sources of supply.

Political scientists and criminologists expect that for any law, there will be some level of non-compliance. But what the United States experienced after 1920 was far more than what the pro-Prohibitionists foresaw. This, in turn, sent the federal government scrambling to augment what turned out to be an underfunded and understaffed administrative system that would eradicate and punish those responsible for the alcohol supply. Given that the Eighteenth Amendment had entrusted the 48 U.S. states with equal responsibility for enforcement alongside the federal government, police forces and the courts at all sub-national levels became positively overwhelmed with Prohibition-related cases. As our case study will show, it ultimately pitted jurisdictions against each other, severely undermining the inter-governmental cooperation needed to make the Amendment work. 
Our geographical perspective on National Prohibition adds to the existing historiography on the subject. Underpinning much of the literature is a desire to explain why Prohibition was abandoned. For some time after 1933, social commentators and historians looked at Prohibition as a 'noble experiment' that failed in the face of an overwhelming and unending tide of peripatetic rum runners, gangsters, speakeasy owners, and loose-living flappers who could pop up anywhere like they were cockroaches. Since the 1970s, however, more nuanced interpretations have emerged that consider Prohibition as yet another Progressive Era social reform movement that managed to morph prevailing attitudes about temperance into a widespread, utopian desire for an outright ban, an idea that both rural and urban inhabitants, including women and the middle class could latch onto. In gaining such widespread support, through calculated use of the national media, pro-Prohibitionists successfully made their cause into a national issue. They had infused their social movement into the national scale.

For many constitutional scholars, the Eighteenth Amendment is almost in the same class as the abolition of slavery (the Thirteenth Amendment) (Kersh and Morone 2002). Both amendments represent the strongest national prohibitory mandates that the U.S. federal government has ever made over personal morality. Both tried to curtail unacceptable practices not only in public but in the home itself. And while all other constitutional articles and amendments have come to apply universally to the citizenry, they are not prohibitory but enabling - granting rights to free speech, bear arms, assemble, vote, etc.

The problem with both of the prohibitory amendments, is that while they erupted out of publicly supported ideals, when it came time for compliance to them locally and in private (and in practice), many Americans acted as if the law did not apply to them or that somehow their non-compliance would escape notice. (In the case of Prohibition, it was common knowledge that high-profile politicians and celebrities were publicly "dry" but privately "wet.") And because of that, the changes in cultural values and practices that the Amendments hoped to instill did not immediately materialize. In fact, things actually got worse. The Thirteenth Amendment legislated in a de jure sense the manumission of enslaved peoples, but it did not in de facto abolish the root problem: racial discrimination. The decades following 1865 included the carpetbaggery of Reconstruction, the horrific conditions and maltreatment encountered in the informal slavery of sharecropping (to which the federal government largely turned a blind eye until the 1930s), redlining and the calcification and Africanization of northern urban slums, etc. Similarly, the Eighteenth Amendment criminalized the commercial handling of alcohol, but it did not foster strong, pervasive, cultural attitudes against alcohol consumption or even private possession (Clark 1976; Kobler 1973).

This, however, is what the Eighteenth Amendment and the Volstead Act did do: small breweries collapsed under the financial strain, allowing for 
several large brewers like Anheuser Busch, Pabst, Miller, and Strohs to control the national beer market after the Amendment's repeal in 1933 (McGahan 1991). It also forced some manufacturers into other lines of business, e.g. soft drinks, malt syrups and ice cream. The California wine industry, established in the 1870 s, was nearly wiped out. The thriving illegal alcohol industry fueled changes in gender roles and normative patterns of American sexuality. The cocktail developed as a result of bartenders attempting to cover the flavor of cheap grain alcohols. Churches struggled to retain access to communion wines. Availability in "wet" neighboring national states in Mexico and the Caribbean increased tourism to these areas. Crime syndicates grew from regional to international in their scope.

In effect, the Thirteenth and the Eighteenth Amendments addressed the legal economy of slavery and alcohol, but they could not legislate the moral economy - that is, the public assent-needed to give them full force and a higher rate of compliance. For the Thirteenth Amendment, the United States is still working on creating that assent (although it has been making some progress - which is part of the reason why so many in the United States and around the globe celebrated the 2008 election of Barack Obama). But with the Eighteenth Amendment, the United States at the federal level/ national scale simply gave up. And while shifting economic and political conditions associated with the Great Depression and the rise of the New Deal are now the most commonly accepted explanations for why the abandonment of the Eighteenth Amendment and the Volstead Act happened, we think that the existing historiography gives short shrift to the spatiality of Prohibition, namely to the administrative nightmare created by shared responsibility for enforcement across state levels/spatial scales, and to continued patterns of extramurality that came to exist due to the blind eye that many local officials turned toward alcohol during Prohibition.

\section{A Historical Archaeo-Geographic Case Study: Prohibition in California}

Material evidence of National Prohibition is easily traced in household archaeological assemblages. Beverage containers are easily identified based on their shape. Brandy, whiskey, bitters, rum, beer, wine, milk and soda bottles are easily identifiable based on their body, neck, finish, base, and embossing attributes, and have been remarkably conservative in their respective forms over the last 150 years. While the poorest of families prior to the introduction of automatic bottle manufacture in 1903 reused and resold bottles, it is safe to assume that most bottles deposited at a site were originally acquired for their original contents. Therefore, it is possible to compare pre-Prohibition, Prohibition, and post-Prohibition sites to 
Table 1 Beverage container profiles at six California archaeological sites

\begin{tabular}{|c|c|c|c|c|c|c|c|}
\hline \multirow[b]{2}{*}{ Site } & \multicolumn{2}{|c|}{$\begin{array}{l}\text { Before Prohibition } \\
(-1920)\end{array}$} & \multicolumn{3}{|c|}{$\begin{array}{l}\text { During Prohibition } \\
(1920-1933)\end{array}$} & \multicolumn{2}{|c|}{$\begin{array}{l}\text { After Prohibition } \\
(1933-)\end{array}$} \\
\hline & $\begin{array}{l}\text { Hancock } \\
\text { Rancho }\end{array}$ & $\begin{array}{l}\text { Zeta Psi } \\
\text { Fraternity }\end{array}$ & $\begin{array}{l}\text { Cordes } \\
\text { Family }\end{array}$ & $\begin{array}{l}\text { Zeta Psi } \\
\text { Fraternity }\end{array}$ & $\begin{array}{l}\text { Crags } \\
\text { Country } \\
\text { Club }\end{array}$ & $\begin{array}{l}\text { Coney } \\
\text { Ranch }\end{array}$ & $\begin{array}{l}\text { Sepulveda } \\
\text { Adobe }\end{array}$ \\
\hline Location & $\begin{array}{l}\text { Los } \\
\text { Angeles }\end{array}$ & Berkeley & $\begin{array}{l}\text { Santa } \\
\text { Monica }\end{array}$ & Berkeley & Malibu & $\begin{array}{l}\text { Santa } \\
\text { Rosa }\end{array}$ & Malibu \\
\hline Dates & 1885-1909 & $1876-1920$ & 1923 & 1923 & 1920 s & $1940-1950$ & 1950 \\
\hline $\begin{array}{l}\% \text { in assemblage } \\
=\text { alcohol } \\
\text { containers }\end{array}$ & 56.6 & 93.5 & 85.2 & 83.6 & 81.6 & 74.8 & 60.9 \\
\hline \% Milk & 15.0 & 4.2 & 5.8 & 0 & 0.9 & 0.2 & 1.9 \\
\hline$\%$ Soda & 28.3 & 2.1 & 8.8 & 16.2 & 17.3 & 25.2 & 27.5 \\
\hline $\begin{array}{l}\% \text { Unidentified } \\
\text { liquor }\end{array}$ & 16.6 & 15.2 & 50.0 & 8.4 & 15.4 & 37.4 & 9.7 \\
\hline \% Whiskey & 18.3 & 8.7 & 26.4 & 0 & 0 & 1.1 & 15.9 \\
\hline$\%$ Wine & 11.7 & 26.1 & 8.8 & 6.6 & 18.2 & 25.3 & 19.6 \\
\hline \% Beer & 10.0 & 43.5 & 0 & 68.6 & 48.0 & 11.0 & 15.7 \\
\hline $\begin{array}{l}\text { Number of } \\
\text { containers } \\
\text { in assemblage }\end{array}$ & 60 & 46 & 34 & 166 & 104 & 199 & 51 \\
\hline
\end{tabular}

evaluate what, if any, short term and enduring impacts Prohibition had on American households.

For this discussion, we draw upon evidence from six California historical archaeological sites that include assemblages that predate, correspond to, and post-date the period of Prohibition (Table 1). Pre-Prohibition period assemblages are drawn from the Los Angeles household of Henry and Ida Haraszthy Hancock (1885-1909), and the Zeta Psi Fraternity of the University of California, Berkeley (1876-1920). These assemblages were selected for several reasons-they were consistently analyzed by one archaeologist, they each contain assemblages that are chronologically attributable to one period or another, and they have good historical association with specific families. Therefore, we can consider the assemblages for patterns that they reveal about general habits of the population without sacrificing an understanding of how specific communities shaped their household practices during these periods of time.

Prohibition period sites include a 1923 dumpsite from the Cordes Family of Santa Monica, a 1923 dumpsite from the Zeta Psi fraternity, and a 1920s dump associated with the Crags Country Club of Malibu, a private drinking establishment for the wealthy of Los Angeles during Prohibition.

Despite the widespread availability of public trash collection in most urban centers during Prohibition, many households chose to bury their trash to hide evidence of illicit drinking rather than put it out for pick-up. 
This was the situation for both the Cordes housesite, which was occupied by a Santa Monica police officer and his family, and the fraternity, whose alcoholic beverage consumption endangered their position on campus. The Crags Country club was located on private rural land and had no dump access.

Post-Prohibition sites are drawn from the 1950s Sepulveda Adobe household dump, also in Malibu, and the 1940s-1950s Coney ranch dump, from Santa Rosa. Both are located in rural areas, thus the recovery of large amounts of domestic trash that would otherwise have been picked up by public waste management in urban areas. Both are also second homes for the families who created the deposits. We mention this because as second homes, these sites may have slightly different beverage consumption profiles than found at primary residences. However, since both deposits were created under similar social circumstances, their differences are somewhat mitigated.

A quick note-comparisons between sites are done based upon percentages of particular beverage containers found in each site. These percentages were calculated based upon the minimum number of vessels represented in each assemblage. The percentages do represent the proportional volume of each beverage category discussed. We are not attempting to reconstruct specific drinking habits so much as to compare disposal practices and infer from those patterns the social behaviors represented. It would be possible to calculate the relative amounts of brandy, whiskey, beer and soda represented in these assemblages, but such an exercise is fraught with a range of problems and ultimately, would only distract us from the intent of our paper.

\section{Possible Patterns of Consumption Before Prohibition}

The households of the Hancock family and Zeta Psi Fraternity represent two different household extremes for the pre-Prohibition period: one is composed of women and children, the other consists solely of young male college students. However, the Hancocks and the fraternity 'brothers' would have been elite social peers.

Ida Hancock lived as a widow during most of the Rancho's extensive occupation (1889-1909) with two young sons, Allan and Bertram. A third son died in infancy. The assemblage contains evidence that Ida paid close attention to maintaining the health of the sons who survived. The "soda" bottles from this site contain mainly mineral waters rather than the sweetened carbonated beverages we think of as soda ("pop"/"soft drinks"). Before Prohibition, mineral waters were seen as both a morally upright temperance drink as well as a general health beverage. Just as vitamin- 
enriched "flavored waters" are a current health rage, so too were soda waters in the late-nineteenth and early-twentieth centuries. Similarly, milk was promoted as a healthy food beverage for children. The relatively high percentage of milk containers represented in the assemblage compared to other households should perhaps be construed in a similar way.

By no means, however, should the Hancocks be viewed as teetotalers. There is clear evidence of alcoholic beverage consumption in the household, as reflected not only in the container profile in Table 1, but also in the fine tumblers and stemwares that were also recovered. The amount of whiskey and gin bottles suggests that the Hancocks may have been consuming their alcohol "neat" (straight), although the soda bottles in the assemblage could be an indication that alcohol was being mixed with nonalcoholic liquids (e.g. 'scotch and soda' and 'gin and tonic'). Interestingly, Ida's family - the Haraszthy's - founded one of the first California vineyards, but evidence of wine consumption is modest when compared to the Zeta Psi brothers.

The Zeta Psi brothers consumed significantly less soda and whiskey than the Hancock family, and much more beer and wine. Their beer consumption is especially worth noting. Beer has an important range of social and ritual meanings in fraternal life (see Wilkie 2010) and the high percentage of beer bottles in the assemblage is reflective of those practices. Local and imported wines and champagne bottles found at both the fraternity and Hancock household sites may also speak to particular class-articulated performances on the part of the elite. As we will see, however, Prohibition led to significant changes in these performances in California.

\section{Possible Patterns of Consumption During Prohibition}

Three sites contain Prohibition-period beverage consumption assemblages: a dump associated with Zeta Psi fraternity, a dump associated with the elite Crags Country Club, and a household dump associated with the Ernest Cordes family of Santa Monica. The Cordes were a working-class/lower middle-class household, with Ernest employed as a police officer and his wife Katie working as a full-time mother to their two children. Since Zeta Psi is the only site where we can compare pre- and Prohibition period assemblages, we'll start our consideration with them.

Several trends are immediately noticeable between the two Zeta Psi assemblages. The amount of soda containers doubled, but the percentage of hard liquor and wine containers declined. Gordon's London Dry Gin-a very popular illegal import during Prohibition—and brandy-one labeled as "medicinal" - are the only products specifically identified. Importantly, a number of California wineries were able to stay afloat during Prohibition 
by producing medicinal brandy wines. The ability of the fraternity members to access these wines during Prohibition may speak to their socioeconomic status (the fact that they knew physicians who would be willing to write prescriptions for this 'medication'). That they desired to acquire wine also speaks to their social positioning.

Most notable, however, is the increased percentage of beer bottles as well as the actual characteristics of the bottles themselves. Among the beer bottles were both "full-leaded" and "unleaded" near beers manufactured by Anheuser Busch, Stroh, and Pabst Blue Ribbon (beers that supposedly had had the alcohol removed). Some breweries sold the near beer extract on the black market as "hootch" while some never removed the alcohol at all, and only changed the bottle and its label under the working assumption that they would not get caught by federal Prohibition agents. The increase in soda bottles in the assemblage may reflect greater reliance on temperance beverages, or more likely, the need to mix low-quality, poortasting hootch with something to improve the flavor.

Prohibition legislation allowed for the consumption of alcohol that had been produced and purchased previous to the Eighteenth Amendment and Volstead Acts's enforcement date, January 16, 1920. This resulted in a thriving counterfeiting trade in the manufacture of labels with pre-Prohibition dates. With a counterfeit label, products could be passed off as an older vintage. In addition, glassworks began making bottles that looked older than they were by acid washing to remove evidence of seams or molding shapes that appeared "older." At the Zeta Psi Prohibition pit, all of the wine bottles had been acid washed, so superficially they appear to be examples of older hand-blown bottles when close examination shows that they were made by machine.

Oral history provides some additional context to the artifactual data. Fraternity brothers from the Classes of 1925 and 1929 recalled frequenting speakeasies in the neighboring town of Emeryville (Wilkie 2010). Drinking off campus was supposedly easier than risk being caught with contraband by administrators. Several newspaper articles in the Oakland Tribune during Prohibition support this in reports about University of California student alcohol violations (usually loud parties on campus) as well as the university's official response (the Dean of Men or Student Affairs generally investigated, threatened expulsion, but often did nothing.)

Going off campus to drink, however, had its dangers. For example, on May 15, 1922, just days before the annual spring graduation, Berkeley police picked up four members of the senior graduating class as they returned to campus at 5:30 a.m. in an automobile that had been 'borrowed' without permission from a younger student. The four-who included the son of a local minister, members of various sports teams, and fraternity brothers (not Zeta Psi)—were intoxicated and accompanied by a 
man they had met and enlisted the prior evening to take them to various speakeasies in his town of residence, Emeryville. In addition to facing criminal charges for auto theft, the students were in trouble for their drunkenness, having violated the school's code of student conduct. Within a day, one had voluntarily withdrawn from school, another was removed as a graduation speaker, while the fates of the other two hung in the balance (there was no follow-up article) (No author 1922).

The connection that oral histories and the newspapers make between the University of California at Berkeley and the City of Emeryville are important, for they allow us to position the Zeta Psi assemblage firmly within a spatial story of extramurality and into the spatiality of federal statehood as it existed under Prohibition. Briefly, Emeryville is a 1.2 square-mile independent municipality bounded by San Francisco Bay to the west, Berkeley to the north, and Oakland to the east and south. In the late-nineteenth and early twentieth-centuries, it was nationally famous for its horseracing track and as a place where city officials turned a blind eye to off-track gambling as well as prostitution, most of which occurred in, above, or near the dozen or so saloons that had been established near the racetrack's entrance. This prior history of leniency (as well as the city's bayside location) made it an easy haven for bootleggers and rumrunners after 1920. Some saloons had closed with Prohibition, but others operated as restaurants that continued to clandestinely sell and serve alcohol. These places were joined by other speakeasies that popped up throughout the small city (Emeryville Historical Society 2005).

In 1921, a popular Emeryville destination was a private fenced-in amusement park and picnic ground called Shell Mound Park. That August, a small coterie of federal Prohibition agents raided the place in search of alcohol violations, finding one liquor bottle among a group of picnickers. In trying to seize the bottle, the picnickers rebelled against the federal agents, a gun discharged, and a riot ensued during which a larger group of park attendees corralled the feds while another group began preparing a lynching tree. As the Oakland Tribune reported it, the agents were saved only by the arrival of members of several municipal police forces from other jurisdictions from around the East Bay region after it had become clear that Emeryville's three-man squad could not handle the melee (No author 1921a).

The following week, another article appeared in the Oakland Tribune, the first of at least a dozen printed over the next 12 years, that addressed the intergovernmental problems associated with Prohibition enforcement in Emeryville. In this case, California State Prohibition Director, E. Forrest Mitchell stated that the Shell Mound Park incident was evidence of how complacent Emeryville's mayor of 25 years, Walter H. Christie, was on the enforcement of federal law at the local level. Unlike other surrounding 
municipalities, Emeryville had not yet enacted a Prohibition enforcement ordinance that would mandate that local police prioritize compliance and that would serve notice to violators that if caught they would be prosecuted. In this article, Christie countered these charges, saying that his police force had not acted aggressively on drinking violations in Shell Mound Park because it was private property. As such, he believed that the owners should be responsible for keeping order there. But, as a public official he said that he believed that he was duty bound to uphold the law of the land regarding Prohibition even though he had not supported having a local Prohibition ordinance, because of the potential expense to taxpayers. Enforcement would mean having to hire more officers. At this time, Christie also came out publicly as saying that even though he'd keep his opinions about the Eighteenth Amendment to himself, he nevertheless did not agree with it. Such press could only have enhanced Emeryville's role as a vice haven (No author 1921b).

Within 4 years, non-compliance had become so problematic that the federal government assigned a permanent squad of Prohibition agents to work exclusively in Emeryville. In a 1925 article, Christie again defended his municipality, but this time setting its seeming non-compliance within a broader geographical and context. First, he said, Emeryville was the "victim" of larger cities around it (San Francisco, Oakland, and Berkeley). Only five people arrested in more than 34 local raids that had been conducted by his police force in 1924 were from Emeryville proper. The problem of non-compliance was coming from outside, he lamented, and this was going to cost his constituents money. Second, before April 1, 1925, all fines collected as a result of raids within the municipality went to the town treasurer and could be used to support Prohibition enforcement. Christie noted that Emeryville had used these fines and forfeitures to hire two additional full-time men at the cost of $\$ 3,360$ in 1924 and had retained a "special squad" on a part-time basis that had added $\$ 3,500$ in expenditures in 1924. A change in California state law in early 1925, however, required that any fines collected in Class 5 and 6 towns (of which Emeryville was one) to be forwarded to the county treasurer instead of the local municipality. The rationale stemmed from the fact that many Prohibition cases in California were not heard at the municipal level but at the county level. The counties wanted the fines to help offset their expenses, and thus pushed for a blanket law that would require that all fines collected be forwarded to the county.

Mayor Christie saw this as a huge structural problem. He argued that if Emeryville was to uphold federal and state Prohibition laws through investigation, arrests, and evidence provision-all necessary in getting convictions no matter the court level-then Emeryville needed a special appropriation from a higher level of government or else it needed to be 
able to keep the fines collected in its local municipal court. Otherwise the cost of enforcement would be in excess of the local annual budget (No author 1925). The amount of animosity that he harbored toward Alameda County, the State of California and the federal government on this issue was palpable.

This raises many questions for future research regarding the performance of statehood during Prohibition. To what extent were smaller municipalities hamstrung in their attempts to comply with federal law given the actions of intervening levels of government like the county and state? In this instance, the actions on the part of the State of California and Alameda County had allegedly contributed to a problem for Emeryville. Or, was this intergovernmental confusion simply an excuse for Christie and Emeryville to turn a blind eye to practices that were part of the local culture of the place he had governed since its incorporation? Throughout the country there were hundreds of municipalities with reputations similar to Emeryville's. What were the intergovernmental dynamics in which these places were embedded?

Returning to the archaeological assemblages, Berkeley's Zeta Psi brothers had older generational social peers in Malibu's Crags Country Club. In fact, at least one of the Zeta Psi brothers had a family member who belonged. Originally founded before Prohibition as an elite hunting club, Crags consisted of a club house and members had the option of building a cabin on the property. During Prohibition, the remote and private nature of the club and its cabins made it a place where liquor could flow freely. Not coincidently, the club disbanded shortly after Prohibition's repeal in 1933 (during the Great Depression when the American economy was at low ebb).

Many historians have assumed that beer consumption greatly decreased during Prohibition. Explanations involve the obtrusive nature of shipment in barrels, and the relative ease of hiding hard alcohol (which provided more of a kick in any case) in small bottles and flasks. Zeta Psi and Crag's encourage us to question that assumption. Like Zeta Psi, Crag's Country Club was a uniquely masculine space. At Crags, beer was a much larger proportion of the beverages represented than might be expected, accounting for near half of the bottle recovered. At the Zeta Psi site, while the 114 beer bottles greatly outnumbered the 11 wine bottles and 14 hard liquor bottles, they do represent a smaller per container servings and lower alcoholic content. In any case, the archaeological record at both places suggests that beer consumption remained important during Prohibition, most likely due to its masculine associations. Whether in the fraternity hall, a hunting lodge, a sporting event, or a military garrison, beer was a matter of ritual. In the Zeta Psi case, it continued to be consumed, even if its form was radically altered in the form of near beers. Crags, however, was not consuming 
near beers. Manufacturer marks older than other materials from the site suggest that the club had either stockpiled before January 1920, acquired older stocks of beers after enforcement began, or managed to acquire new beer bottled in older bottles.

The amount of soda consumed at Crags' is similar to that used at the fraternity house, while the amount of wine and hard liquor is greater. As was the case at Zeta Psi, Gordon's London Dry Gin was recovered, as were acid washed wine and champagne bottles. The high incidence of wine at the site may be related to the ease with which these products could be obtained from local vineyards and counterfeited. Initially confusing, was the recovery of several short amber bottles that appear to be Italian-style wine bottles with applied glass handles at the neck. These were also seamless. There is no real historical precedent for such a bottle shape, but certainly, they look like they should be "old". Several references suggest that these contained brandy and the bottle shape was limited to the period of Prohibition (Munsey 1970). Access to counterfeited as well as illegally imported liquors allowed for the members of Crags to stay wet in a dry nation.

In the case of Crags, the increase in soda bottles is most certainly tied to alcohol consumption. Recovered from the site along with ginger ales and imported Irish mineral waters were sodas used as mixers. Other foodstuffs recovered from the site hint at the specific drinks that might have been consumed: pickle, horseradish, Worcestershire sauce, olive jars, cherry bottles, bitters bottles, Cinzano vermouth and gin. World-famous California bartender Jerry Thomas' "Le Bon Vivant" cocktail recipe book (originally published in the 1860s but reissued in 1928) includes the recipe for the Bloody Mary cocktail (invented in 1920) that required Worcestershire sauce, horseradish, vodka and tomato juice. The classic Martini (originally developed by Thomas in Martinez, California) required bitters, gin, maraschino, and vermouth. The gin and tonic was already a classic. The Soda Cocktail required white sugar, bitters and plain soda. The Vermouth Cocktail was a mixture of whiskey, maraschino, vermouth and bitters. The Tom Collins included soda, gum syrup and whiskey-although brandy or gin could also be used-topped off with a maraschino cherry.

While cocktails became a popular way to cover the taste of bad liquor, in the introduction to the 1928 edition of the Bon Vivant, Herbert Astbury tried to recast the circumstances of Prohibition with an aura of class, high society, and sophistication: "In these decayed and evangelical times, when drinking has reverted to a savage guzzling of liquid dynamite, the name of Jerry Thomas arouses no answering spark of manhood from the craven victims of bootleg liquor or the cowed and beaten slaves who labor in the gloomy galleys of the Anti-Saloon league. But to the ancients who weep beside the bier of a lost art it brings back beautiful memories of golden 
fizzes and stimulating juleps, of cobblers, slings, and sangarees." (Intro, Thomas 1929).

The working-class drinking of Ernest Cordes' family, however, shows no tendency toward the niceties of the mixed drinks from Crags Club. The family's beverages, aside from two milk bottles, three bottles of Hires Root Beer, and three bottles of wine, is dominated by 26 hard liquor bottles, nine of which are whisky hip flasks. Prohibition oral histories suggest that the pint flask was a common gift or tax paid by bar owners to local law enforcement to ensure a blind eye toward illegal activities (Wilkie 2010). It is no wonder that Ernest Cordes buried the empties in the back of the house. Still, we should not be harsh in our judgment of Ernest given that enforcement along the coastal areas of California was weak. An officer who attempted to enforce Prohibition, especially in areas that did not want it, would have been as likely to be ostracized by his community as by his fellow officers. It was probably enough to drive one to drink. As does the conclusion we draw from these assemblages: the geography of compliance and non-compliance was an extraordinarily complicated matter, variegated by class, locational setting, scale, municipal proclivities as well as engagement with other levels of the federal state.

\section{Possible Patterns of Consumption After Prohibition}

When Prohibition was repealed in 1933, Anheuser Busch (who, like other large brewhouses, had survived by siphoning alcohol from their beers and selling it as hootch) celebrated by sending the still-famous Clydesdale horse and wagon team with a load of "Repeal Ale" to Franklin Delano Roosevelt in the White House. The U.S. had not dried out, but what they drank, what they drank it with, and who made it, had been changed forever. Two mid-twentieth-century sites provide some insights into how post-Prohibition drinking looked. For this we turn to the Sepulveda Adobe, which was used as a summer home by an unidentified southern California family in the 1940s and 1950s, and the Coney Ranch outside of Santa Rosa in northern California. Joseph Coney, the owner of the Coney Ranch, was a wealthy Santa Rosa business man who entertained large groups of associates there each summer, including the Sonoma Trailblazers, an organization that re-enacted western life with multi-day trail rides that ended at the ranch with lots of drinking and celebrating.

In both the Sepulveda and Coney assemblages, soda accounts for larger percentages of the beverage containers than in previous assemblages. There are, however, far more Coca-Cola, Pepsi Cola, and flavored, sugary sodas than mineral waters and tonics. Hard liquor bottles are within the range found in pre-Prohibition period sites. Beer consumption does not account 
for much of either assemblage-this despite Coney's social groups emphasizing masculine pursuits. The Sepulveda assemblage includes multiple examples of brandy and rum, liquors that were widely available during Prohibition. Surprisingly, both assemblages is that they contain impressive amounts of wine, but not the kinds of fine wines of the pre-Prohibition or even Prohibition period. From the Coney ranch, multiple examples of "Petri" jug wine were recovered (Petri had been a pre-Prohibition wine maker who sold his winery and rebought it after repeal. He produced dessert wines to accommodate new American tastes for sweet alcoholic beverages.) The Sepulveda assemblage also includes examples of jug wines by Ernest and Julio Gallo, Regina Wine, Christian Brothers, and Roma Wine. Roma wine, a port bottled in Fresno, advertised itself as "America's favorite wine because it tastes the best." Print ads demonstrate that wine consumption-even that of sweet grapey port-was seen to connote a certain kind of sophistication (Merizan 2009). Ida Hancock would not have been able to recognize her family's legacy.

Sweet cocktails had been the result of America's gravitation in preferences toward sweet sodas. Not until the last quarter of the twentieth century would national beer and wine monopolies created in the wake of Prohibition be truly challenged by small-scale microbreweries and vineyards that favored craftsmanship over bulk production and drier tasting products over the sweet.

\section{Conclusions and Suggestions for Future Research in Historical Archaeo-Geography}

To conclude, this paper has not been intended to be an exhaustive discussion of Prohibition and its impacts. Nor is our intent to demonstrate what a grand failure Prohibition was. Instead, despite Prohibition's inability to dry out the country, it managed to reshape American consumption habits on a gross level. Further, it forced individuals and the federal state at all levels into new sets of relationships as a result of the attempt to enact geographically universal regulation in a world characterized by local jurisdictional variation.

Specifically, what the various assemblages suggest is that fraternities and clubs continued to recognize the ritual meanings of shared beer consumption. Elite households like the Hancocks used resources available to them to subvert the system and created new ways of reifying their class identities through new modes of acquiring and consuming alcoholic beverages. The working-class Cordes worked within the new illegal economy to acquire alcoholic beverages; it is worth wondering whether Cordes himself redistributed alcohol to other members of his social network. Ultimately, while 
Prohibition may have changed what Americans drank, it did little to modify the fact that Americans did drink-even when they were not supposed to.

Social theorist Scott (1998) notes how important it is to look at the world as if we were "seeing like a state." His agenda, of course, is to unmask and de-naturalize the instruments of state hegemony that dictate the contours of everyday life. His ideas have played particularly well with human geographers as they attempt to clarify the scalar aspects of statehood and their connections to the micro-scale, quotidian world of the human subject. As our work suggests, however, state hegemonies are not absolute-and as Scott concurs in another book, Weapons of the Weak (1985) - subjects have the capacity to develop tactics to resist or ignore attempts at state intervention. Not every effort to erect state hegemony looks the same or fosters the same set of authoritarian results.

In summation, an historical archaeo-geography of American federalism and National Prohibition allows for two things: (1) reconsideration of the top (recent) stratigraphic archaelogical layers in light of federal statehood as it relates to the manufacturing, packaging, and disposal of various material forms; and (2) the potential activation of a new constellation of archaeological sites-facilities that were run or funded by various levels of the state within the federal system. What clues can the archaeological record add to our understanding of everyday life-the practice of personhood-within these state places? At least, that is the transformative question that the historical geographer will want to ask. For the historical archaeologist, the countering query will be: into what broader geographical networks of statehood might these sites, assemblages, and artifacts and the subjects who created them, fit? The beauty of transdisciplinarity, we are finding, is complementarity. Historical geography enriches archaeology with the concern for the social construction of scale. Historical archaeology enriches geography with evidence of the materiality of everyday life. Together, through the practice of historical archaeo-geography, both fields will be the better for it.

\section{Open Access}

This article is distributed under the terms of the Creative Commons Attribution Noncommercial License which permits any noncommercial use, distribution, and reproduction in any medium, provided the original author(s) and source are credited. 


\section{References}

Beaudry, M. C. (editor)

2006. Findings: The Material Culture of Needlework and Sewing. Yale University Press, New Haven.

Blocker, J. S.

1976. Retreat from Reform: The Prohibition Movement in the United States, 1890-1913. Greenwood Press, Westport, CT.

Brenner, N.

2001. The Limits to Scale? Methodological Reflections on Scalar Structuration. Progress in Human Geography 25(4):591-614.

2004. New State Spaces: Urban Governance and the Rescaling of Statehood. Oxford University Press, Oxford.

Brooks, J. F., C. R. DeCorse, and J. Walton (editors)

2008. Small Worlds: Method, Meaning, and Narrative in Microhistory. School for American Research, Santa Fe.

Buchli, V., and G. Lucas (editors)

2001a. Archaeologies of the Contemporary Past. Routledge Press, London and New York.

Buchli, V., and G. Lucas

2001b. The Archaeology of Alienation: A Late Twentieth Century British Council House. In Archaeologies of the Contemporary Pastpp, edited by V. Buchliand, and G. Lucas, pp. 158-167. Routledge, London and New York.

Butzer, K. W.

1964. Environment and Archeology; An Introduction to Pleistocene Geography. Aldine Pub. Co, Chicago.

1976. Early Hydraulic Civilization in Egypt: A Study in Cultural Ecology. University of Chicago Press, Chicago.

1982. Archaeology as Ecology: Method and Theory for a Contextual Approach. Cambridge University Press, Cambridge, New York.

Butzer, K. W., J. D. Clark, and H. B. S. Cooke

1974. The Geology, Archaeology and Fossil Mammals of the Cornelia Beds, O.F.S. Nasionale Museum, Bloemfontein.

Butzer, K. W., and Omo Research Expedition

1971. Recent History of an Ethiopian Delta: The Omo River and the level of Lake Rudolf. University of Chicago, Chicago.

Clark, N. H.

1976. Deliver us from Evil: An Interpretation of American Prohibition (1st ed.). Norton, New York. 
Conzen, M. P.

1993. The Historical Impulse in Geographical Writing About the United States, 1850-1990. In A Scholar's Guide to Geographical Writing on the American and Canadian Past, edited by M. P. Conzen, T. Rumney, and G. Wynn, pp. 3-90. University of Chicago Press, Chicago.

Creswell, J. W.

2003. Research Design: Qualitative, Quantitative, and Mixed Methods Approaches (2nd ed.). Sage Publications, Thousand Oaks, CA.

De Blij, H. J.

2005. Why Geography Matters: Three Challenges Facing America: Climate Change, the Rise of China, and Global Terrorism. Oxford University Press, Oxford; New York, NY.

de Certeau, M.

1984. The Practice of Everyday Life. University of California Press, Berkeley.

Dear, M.

1988. The Postmodern Challenge: Reconstructing Human Geography. Transactions of the Institute of British Geographers 13(3):262-274.

Denevan, W. M., National Science Foundation (U.S.)

1986. The Cultural Ecology, Archaeology, and History of Terracing and Terrace Abandonment in the Colca Valley of Southern Peru. Department of Geography, University of Wisconsin-Madison, Madison, WI.

Dikshit, R. D.

1971. Geography and Federalism. Annals of the Association of American Geographers 61(1):97-115.

1976. The Political Geography of Federalism: An Inquiry into Origins and Stability. Macmillan, London.

Domosh, M., and K. M. Morin

2003. Travels with Feminist Historical Geography. Gender, Place \& Culture 10(3):257-264.

Duncan, J. S.

1980. The Superorganic in American Cultural Geography. Annals of the Association of American Geographers 70(2):181-198.

Earle, C.

1992. The Practice of Geographical History. In Geographical Inquiry and American Historical Problems, pp. 1-23. Palo Alto: Stanford University Press.

1995. Historical Geography in Extremis? Splitting Personalities on the Postmodern Turn. Journal of Historical Geography 21(4):455-459.

2003. The American Way: A Geographical History of Crisis and Recovery. Rowman \& Littlefield, Boulder. 
Earle, C., L. Dilsaver, and D. Ward

1989. Historical Geography. In Geography in America, edited by G. L. Gaile, and C. J. Wilmott, pp. 156-191. Merril, Columbus, OH.

Elazar, D. J.

1981. The Evolving Federal System Proceedings of the Academy of Political Science 34 (2):5-19.

Emeryville Historical Society

2005. Images of America: Emeryville. Arcadia, San Francisco.

Geography Education Standards Project (U.S.), American Geographical Society of New York, Association of American Geographers, National Council for Geographic Education, and National Geographic Society (U.S.).

1994. Geography for Life: National Geography Standards 1994. National Geographic Research \& Exploration. Washington, DC.

Gonzalez-Ruibal, A.

2006. The Past is Tomorrow. Towards an Archaeology of the Vanishing Present. Norwegian Archaeological Review 39(2):110-125.

Hall, M.

2000. Archaeology and the Modern World: Colonial Transcripts in South Africa and Chesapeake. Routledge, London.

Hartshorne, R.

1939. The Nature of Geography: A Critical Survey of Current Thought in Light of the Past. Association of American Geographers, Lancaster, PA.

Harvey, D.

1973. Social Justice and the City. John Hopkins University Press, Baltimore.

1985. Consciousness and the Urban Experience: Studies in the History and Theory of Capitalist Urbanization. John Hopkins University Press, Baltimore, MD.

1989a. The Condition of Postmodernity. Blackwell, Cambridge, MA, Oxford.

1989b. The Urban Experience. Johns Hopkins University Press, Baltimore.

Herod, A.

2009. Geographies of Globalization: A Critical Introduction. Wiley-Blackwell, Malden, MA; Oxford.

Hicks, D.

2007. The Garden of the World: An Historical Archaeology of Sugar Landscapes in the Eastern Caribbean. BAR International Series 1632. Archeopress, Oxford.

Hicks, D., and M. Beaudry (editors)

2006. The Cambridge Companion to Historical Archaeology. Cambridge University Press, Cambridge. 
Holtorf, C.

2004. From Stonehenge to Las Vegas: Archaeology as Pop Culture. AltaMira Press, Walnut Creek, CA.

Jameson, F.

1998. The Cultural Turn: Selected Writings on the Postmodern, 1983-1998. Verso, London; New York.

Johnson, M.

2007. Ideas of Landscape. Blackwell, Oxford.

Johnston, R. J.

2004. Geography \& Geographers: Anglo-American Human Geography Since 1945 (6th ed.). Arnold; distributed in the U.S.A. by Oxford University PressLondon; New York.

Kay, J.

1991. Landscapes of Women and Men: Rethinking the Regional Historical Geography of the United States and Canada. Journal of Historical Geography 17(4):435-452.

Kersh, R., and J. Morone

2002. How the Personal Becomes Political: Prohibitions, Public Health, and Obesity. Studies in American Political Development 16(02):162-175.

Kobler, J.

1973. Ardent Spirits; the Rise and Fall of Prohibition. Putnam, New York.

Konvitz, J. W.

1985. The Urban Millennium: The City-Building Process from the Early Middle Ages to the Present. Southern Illinois University Press, Carbondale.

Kyvig, D. E.

2000. Repealing National Prohibition (2nd ed.). Kent State University Press, Kent, $\mathrm{OH}$.

Leone, $\mathrm{M}$.

2006. The Archaeology of Liberty in an American Capital: Excavations in Annapolis. University of California Press, Berkeley.

Lightfoot, K.

2006. Indians, Missionaries, and Merchants: The Legacy of Colonial Encounters on the California Frontier. University of California Press, Berkeley.

Low, S. M., and D. Lawrence-Zúñiga

2003. The Anthropology of Space and Place: Locating Culture. Blackwell Publications, Malden, MA.

Ludlow Collective.

2001. Archaeology of the Colorado Coal Field War 1913-1914. In Archaeologies of the Contemporary Past, edited by V. Buchli, and G. Lucas, pp. 94-107. Routledge, London. 
Majewski, R., and D. Gaimster (editors)

2009. International Handbook of Historical Archaeology. Springer, New York.

Marston, S. A.

2000. The Social Construction of Scale. Progress in Human Geography 24(2):219-242.

Marston, S. A., J. P. Jones III, and K. Woodward

2005. Human Geography Without Scale. Transactions of the Institute of British Geographers 30(4):416-432.

McGahan, A. M.

1991. The Emergence of the National Brewing Oligopoly: Competition in the American Market, 1933-1958. The Business History Review 65(2):229-284.

Merizan, J.

2009. Families and Frontier Boys: An Archaeology of Consumerism and Identity Construction in a mid-20th Century California Community. Senior Thesis, Anthropology Department, University of California, Berkeley.

Mettler, S.

1998. Dividing Citizens: Gender and Federalism in New Deal Public Policy. Cornell University Press, Ithaca, NY.

Mitchell, D.

1996. The Lie of the Land: Migrant Workers and the California Landscape. University of Minnesota Press, Minneapolis.

2000. Cultural Geography: A Critical Introduction. Blackwell Publishers, Oxford; Malden, MA.

Mitchell, R. D.

1987. The North American Past: Retrospect and Prospect. In North America: The Historical Geography of a Changing Continent, edited by R. D. Mitchell, and P. Groves, pp. 3-24. Roman and Littlefield, Totowa, NJ.

Morin, K. M., and L. D. Berg

1999. Emplacing Current Trends in Feminist Historical Geography. Gender, Place \& Culture 6(4):311-330.

Mosher, A. E.

2004. Capital's Utopia: Vandergrift, Pennsylvania, 1855-1916. Johns Hopkins University Press, Baltimore.

Mosher, A. E., and D. W. Holdsworth

1992. The Meaning of Alley Housing in Industrial Communities: Examples from Late-Nineteenth and Early-Twentieth Century Pennsylvania. Journal of Historical Geography 18:174-189.

Mullins, P. R.

1998. Race and Affluence: An Archaeology of African America and Consumer Culture. Kluwer/Plenum Press, New York. 
Munsey, C.

1970. The Illustrated Guide to Collecting Bottles. Hawthorne Books, New York.

Murray, W. E.

2006. Geographies of Globalization. Routledge, London; New York.

No author

1921a. Sheriff Begins Inquiry in Rebel Cork Picnic Battle of U.S. Agents and Police. Oakland Tribune, August 8:1.

1921b. State Dry Chief Rapped by Mayor of Emeryville-Threats to Send Sleuths to Clean Up Shellmound Park Evokes Retort. Oakland Tribune, September 3.

1922. U.S. Student Not to Graduate in Auto Case. Oakland Tribune, May 15.

1925. Secret Emeryville Arrests to Land Bootlegger Kings, Vows Dry LeaderAgent's Charges Draw Fire from Mayor Who Blames Neighbors. Oakland Tribune, October 6.

Ogundiran, A., and T. Falola

2007. Archaeology of Atlantic Africa and the African Diaspora. University of Indiana Press, Bloomington.

Orser, C.

1996. A Historical Archaeology of the Modern World. Plenum Press, New York.

2007. The Archaeology of Race and Racialization in Historic America. University Press of Florida, Gainesville.

Pile, S.

1993. Human Agency and Human Geography Revisited: A Critique of 'New Models' of the Self. Transactions of the Institute of British Geographers 18(1):122-139.

Powers, M.

1998. Faces Along the Bar: Lore and Order in the Workingman's Saloon, 18701920. The University of Chicago Press, Chicago.

Price, M., and M. Lewis

1993. The Reinvention of Cultural Geography. Annals of the Association of American Geographers 83(1):1-17.

Rose, G.

1997. Situating Knowledges: Positionality, Reflexivities and Other Tactics. Progress in Human Geography 21(3):305-320.

Rose, G., and M. Ogborn

1988. Feminism and Historical Geography. Journal of Historical Geography 14(4):405-409.

Scott, J. C.

1985. Weapons of the Weak: Everyday Forms of Peasant Resistance. Yale University Press, New Haven, CT. 
Scott, J. C.

1998. Seeing Like a State: How Certain Schemes to Improve the Human Condition Have Failed. Yale University Press, New Haven, CT.

Skocpol, T.

1992. Protecting Soldiers and Mothers: The Political Origins of Social Policy in the United States. Belknap Press of Harvard University Press, Cambridge, MA.

Smith, N.

1987. "Academic War over the Field of Geography": The Elimination of Geography at Harvard, 1947-1951. Annals of the Association of American Geographers $77(2): 155-172$.

Spaeth, S. J.

1991. The Twenty-First Amendment and State Control over Intoxicating Liquor: Accommodating the Federal Interest. California Law Review 79(1):161-204.

Staeheli, L. A., and D. Mitchell

2005. The Complex Politics of Relevance in Geography. Annals of the Association of American Geographers 95(2):357-372.

Thomas, J.

1929. The Bon Vivant's Companion: or, How to Mix Drinks. A.A. Knopf, New York.

Uvin, P.

1995. Scaling up the Grass Roots and Scaling Down the Summit: The Relations Between Third World Nongovernmental Organisations and the United Nations. Third World Quarterly 16(3):495-512.

Vance, J. E. Jr.

1990. The Continuing City: Urban Morphology in Western Civilization. Johns Hopkins University Press, Baltimore.

Voss, B. L.

2008. The Archaeology of Ethnogenesis: Race and Sexuality in Colonial San Francisco. University of California Press, Berkeley.

Warf, B., and S. Arias

2009. The Spatial Turn: Interdisciplinary Perspectives. Routledge, London; New York.

Wilkie, L. A.

2003. The Archaeology of Mothering: An African-American Midwife's Tale. Routledge, New York.

2010. The Lost Boys of Zeta Psi: A Historical Archaeology of Masculinity in a University Fraternity. University of California Press, Berkeley.

Wilkie, L. A., and K. M. Bartoy

2001. A Critical Archaeology Revisited. Current Anthropology 41(5):747-778. 